\title{
American Orientalist Discourse: the Linguistic Formation and Transformation
}

\author{
Mubarak Altwaiji ${ }^{1}$ \\ ${ }^{1}$ Northern Border University, Kingdom of Saudi Arabia \\ Correspondence: Mubarak Altwaiji, Northern Border University, Kingdom of Saudi Arabia. E-mail: \\ mubarak2006ye@gmail.com
}

Received: July 29, 2018 Accepted: August 27, 2018 Online Published: December 29, 2018

doi:10.5539/ijel.v9n1p261 URL: https://doi.org/10.5539/ijel.v9n1p261

\begin{abstract}
The Middle East region had been the epicentre of American orientalist discourse since the American independence from Britain. After independence, American linguists, travellers, missionaries, politicians, sailors and traders scrutinized the anarchy and uncertainty of that region and employed them to produce works that prioritized American identity formation. This research rests on conducting an analysis of how American orientalism was created and how the various encounters between Arabs and America affected the linguistic course of this academia. This study considers the major encounters in the course of Arab-America relationship that brought major transformations to orientalism such as: the Barbary war, the creation of Israel, oil and terrorism. Since the American independence, American orientalism focused on building American identity in comparison with Arabs and their practices. Modern American orientalism has undergone various and huge transformations resulted mostly from formidable threats to American interests and the American retaliations to those threats. These encounters, whether political, economic or military, brought representation of Arabs to the top of American orientalist agenda and left a huge impact on image of Arabs in literature. Therefore, this study is based on the analysis of these different factors in order to know the different perspectives of this orientalism through its different stages.
\end{abstract}

Keywords: American orientalism, Arabs, identity, hegemony, Islamic, linguistic, terrorism

\section{Historical Overview}

American linguistic scholarship on the Middle East represents a pioneering application of Orientalist methods to analyse the existed European discourse and becomes a part of the broader scholarly efforts of the west (Bilgin, 2004, p. 231). Historically, America-Middle East relationship has been highly problematic and premised on an excess of serious tensions and hostile expectations. The two poles of this relationship exaggerated contrasting views that gave tremendous momentum to demonizing each other through politics and cultural work. Political and cultural discourse in the Arab world posits America in the category of the "arrogant, paternalistic, decadent, unfair, cruel and uncaring" power (Moneim \& Edward, 2004, p. 6). Similarly, American politicians and orientalists "tend to see the Arabs through the optic of terrorism" (2004, p. 6) and therefore, Americans believe that a "strategic conception must be adapted" as a "new world order" (Chomsky, 1991, p. 15). Implicit in such assumption is that "old world order" shall be replaced by the new (1991, p. 15). Throughout the ebb and flow of this relationship, American "goals remained consistent, even when it changed rhetoric, strategy or alliances" and "its objectives were delineated in its pronounced doctrines and focus on advancing its geopolitical interests" (Bishara, 2013, p. 2). Though many scholars, while analysing this relationship, refer to the post World Wars as the departure point, this study, however, looks at such analysis as a study of the American rise to hegemony and super power.

The rapprochement between America and other regions is old and dates back to the early eighteenth century British colonial era, when America had a considerable economic growth: "The expansion of the colonial economy thus was especially significant between 1700 and 1775 ...By 1775 the colonial gross product had reached $£ 35,000,000$ sterling. This amounted to about 40 percent of Britain's gross product" (Lemon, 1987, pp. 143-44). During this era, American colonies signed trade agreements with foreign nations and used a trade passage through Arab territory of North African: “...formal treaties of commerce with France in 1778 and with Holland and Spain shortly thereafter stimulated the flows of overseas trade...the flow of goods in and out of the 
colonies remained well below prewar levels" (Walton \& Hugh, 2010, p. 111). This growth led to expansion toward East and West as "Americans hoped to chart their own course in the Atlantic world, trading in markets that offered them the greatest profits" (Lambert, 2007, p. 12). This trade expansion was faced by encounters with Arab Pirates and resulted in American political and cultural determination to directly engage the Barbary States "to extend its newly won independence to overseas commerce" (2007, p. 7). Therefore, it was a certain time for Americans to engage with Arab culture and represent this relationship as a clash between the civilized and uncivilized, enlightened and dark; and human and barbarous. This representation shaped the public understanding of Arabs and their culture. At this particular point, one can detect the roots of American orientalism which was more than a literary discourse; it, however, was a binarism and assertion of power.

The short period that followed American independence in eighteenth century (1795-1805) witnessed the first actual interaction between the young republic and the Arab pirates of North Africa. This military encounter with the pirates was fought between the Western alliance of the United States, Sweden and The Kingdom of Sicily against Arab pirates from Tunis, Algiers and Tripoli. According to historians, this early military encounter has been a "cultural window through which Americans view their opponents with an emphasis on their non-Christian, non-Western, non-modern perspectives" (2007, p. 13). This era in the history of America is an important part in American perception of the Arabs which lays the foundation stone for an academia called American orientalism:

Colonial America, and later the United States, inherited the centuries old ideological schism between Christianity and Islam. The battle, which came to increasingly reflect an economic struggle over trade and shipping rights, had been framed in Europe as a fight between Christian knights and Islamic pirates....This ancient struggle between cross and crescent, with its penchant for human prizes, had already crossed the Atlantic by 1625 (Baepler, 2004, p. 219).

\section{Statement of the Study}

This approach to the formation of American discourse on Arabs leads to preoccupying questions: What is American Orientalism and how old is it? How was the perception of the orient formed? How did Americans come to see themselves as distinct from the Orientals? What are the major transformations in the course of American orientalism? This study establishes a framework for investigating the construction of American orientalism through the journey from independence to hegemony and imperialism.

\section{American Independence}

Independence from Britain gave a unique significance to American culture at this particular era because it was a time of building the national identity and obtaining national autonomy. Both independence and trade prosperity provided the historical excursions that chart definitions of American relationship with the Orient. The American interest in building the national identity in this era becomes a top priority and its mechanism is to engage with the Orient. The crux of nationalism and autonomy of identity rests in a lecture given by Ralph Waldo Emerson, author of Concord Hymn, titled The American Scholar on August 31, 1837. This lecture inexorably demonstrates power and hegemony through shaping identity in opposition with the Other:

If there is any period one would desire to be born in, is it not the age of Revolution; when the old and the new stand side by side, and admit of being compared; when the energies of all men are searched by fear and by hope; when the historic glories of the old can be compensated by the rich possibilities of the new era? This time, like all times, is a very good one, if we but know what to do with it (Emerson, 1981, p. 68).

Orientalism, however, was not new to the American writers and readers because American scholars had been introduced to traditional orientalism through European writings and American "missionaries, tourists, and merchants who sailed from America into the Eastern Mediterranean" (Little, 2002, p. 9). These two sources inspired many American writers to represent and describe Arabs and Arab culture. Among this early American orientalist writings are Susanna Rowson's Slaves in Algiers (1794), Washington Irving's Conquest of Granada (1829) and Mahomet and His Successors (1849), Mark Twain's The Innocents Abroad (1869) and Joseph Stevens Jones's The Usurper (1855?). These writings formed the grounding premise of American orientalism and associated it with the European orientalist social and political approach in explaining the Eastern reality to the American audience. Therefore, no analysis of modern American orientalism can take place without referring to European orientalism. European orientalism is important in the context of historical events that shaped this new orientalism as Robert Young noted: "[I]t combines its critique of Western history with one of the Western historicism, showing the enhancement of the links between the two in the colonial past and the neo-colonial present...For that history lives on: its effects are operating now" (2004, p. 218). This classic orientalism is important, not only as an imperial and hegemonic weapon through which Europe sought colonizing the geography and demonizing the culture, but also to understand the borderline separating two orientalisms; a 
mature one belongs to European superpowers and a new one belongs to a nation rising to power. While European orientalism played a direct role with the colonizers as a "style for dominating restructuring, and having authority over the Orient" (Said, 1977, p. 3), American, however, orientalism did not necessarily serve imperial interests: "the orient was the intense sense of emotional and spiritual connection between Americans and the Holy Land" (Hyde, 2013, p. 27). In succession to the imperial orientalism of the Europe, American orientalism demonstrated a multifaceted pursue of the Middle East which, of course, was less imperial:

In 1776 what little the average American knew about the Middle East and its peoples likely came from two sources: the King James Bible and Scheherazade's Thousand and One Arabian Nights. Few Americans could have found Baghdad or Beirut on a map, and fewer still had climbed the great stone pyramids at Giza or waded the holy waters of the River Jordan (Little, 2002, p. 11).

\section{Linguistic Formation of Representation}

Independence is employed in the first half of this study to explain the role of nationalism in "othering" the Middle Eastern people in favour of constructing a privileged national identity. This superiority and its role in world affairs were first asserted by Thomas Jefferson in 1795 that America is influenced by the French revolution and managed to take off its "oldness" and put on "newness". This new America, according to Jefferson's letter to Tench Coxe, is a "ball of liberty" that will "roll around the globe" and spread both together "light and liberty" to the nations (Jefferson, 1795). At this early era in the history of America, 1828, Jefferson presents America as a spiritual head of nations and a unique world member who carries the world burden and destiny on its shoulders: "American Independence, as one of the surviving signers of an instrument pregnant with our own, and the fate of the world...That form which we have substituted, restores the free right to the unbounded exercise of reason and freedom" (Jefferson, 1826). This belief is asserted later by John Kennedy that America "shall pay any price, bear any burden, meet any hardship, support any friend, oppose any foe to assure the survival and the success of liberty" (Kennedy, 1961). This spirit continues to be the deepest and the vital interest of Americans which conjures the visions, desires and dreams the founders of America.

American identity construction is employed vigorously in examining the Middle East region to enhance the privilege of national identity. People living in the Orient are defined in terms of this new spirit as different from post-independence Americans that Arabs are "well known for their piracy; it is on this that they chiefly subsist. They are of a yellowish complexion, and are very brutal, cruel, and ignorant" (Louis \& Cottineau, 1806, p. 136). In 1806, Denis Louis and Cottineau de Kloguen used a deformed name for the religion of the Arabs calling it Mahometanism instead of Islam. When Louis is asked "[w]hat religion do they [Arabs] follow?", he replies "the Mahometan religion" (p. 136). This manipulation in the names of the Prophet and the religion indicates two things: firstly, this term is a misnomer and an inaccurate name because it suggests that the Muslims worship Muhammad rather than God. Secondly, it establishes a tradition of representation resulting from having in mind Christianity, the religion of Christ, as the basis for representing Islam. Besides, the name Mahometan is vulgarly used because Muhammad is regarded as a Prophet only and Muslims do not speak of Islam as Mahometan or Mohamedanism.

Post-independence identity construction required a distinction between the two territories and nations; identifier and identified: "All identities can possibly exist with their 'difference'... There is no culture or cultural identity which does not have its 'other' of the 'self' " (Derrida, 1992, p. 129). This distinction became "the starting point for elaborate theories, epics, novels, social descriptions, and political accounts concerning the Orient, its people, customs, 'mind,' destiny, and so on." (Said, 1977, pp. 2-3). Therefore, national identity construction implicates production and reproduction of orientalist discourses in order to keep hold of a vigorous pride in the minds of the citizens; in other words, American identity formation is the cornerstone within American orientalist discourse. The construction of American identity prioritizes an identity discourse which competes with the dominant European orientalism that used knowledge on Orient to control it as Turner Bryan says, "to know is to subordinate" (1977, p. 21). This European discourse was a field of production power and hegemony. The tie-up between the two indicates that "there is no power relation without the correlative constitution of a field of knowledge, nor any knowledge that does not presuppose and constitute at the same time power relations" (Foucault, 1977, p. 27). Many approaches to the study of early American orientalism, however, focus primarily on the binarism of " $\mathrm{I}$ " and the "Other" as a salient feature of this new orientalism, paying less attention to three important issues related to American orientalism:

1) Early American discourse, unlike the European discourse, did not demonstrate hegemony and imperial interests though the United States had a considerable economy and army compared to its colonizer, England. It, however, from its very beginning aimed at establishing a unique distinguished identity, 
different from its English and European roots. Scholars, including Edward Said, did not examine the mechanics by which American orientalism was developed and continued but not created.

2) Twentieth Century American orientalism wore a new suit though replicating the European discourse in order to replace the Europeans in colonies through new mechanisms such as human rights, women rights, trade agreements, investment and democracy.

3) Hegemony in American orientalism is a natural phenomenon because this orientalism is an imitation of the European discourse in both ideology and style; it provides cognitive approaches governed by racial and geographical differentiations in which individuals locate themselves in as superior to the "Other".

American identity is confronted with an extraordinary challenge represented by a shift in the social rise from colonized to a rising-to-power nation. This nineteenth-century's American obsession with the Middle East "had taken place in American attitudes toward expansion that was sparked partly by a European scramble for empire" (Digital History, 2014, p. 2). With the fade of the imperial powers, England and France, the United States challenged the Europeans' position in the Middle East and showed a hegemonic interest: "The US has a long-standing geopolitical interest in the region....[It] was regarded as part of the old British Empire, and absolutely essential for the economic, military, and political control of the globe." (Harvey, 2003, p. 20). In place of the European colonizers, the United States filled the vacuum left by the withdrawal of Britain and France using new mechanisms of neo-colonialism and capitalist hegemony:

The control of the Middle East is certainly a cornerstone of Washington's project of global hegemony...The Second World War ended in a major transformation in the forms of imperialism, substituting for the multiplicity of imperialisms in permanent conflict a collective imperialism. This collective imperialism represented the ensemble of the centers of the world capitalist system... This new form of imperialist expansion has gone through various phases (Amin, 2004, pp. 2-6).

Second stage in American orientalism is the stage of the hegemonic discourse and; of course, associating American orientalist academy with the Middle East at this stage is pure imperial: "During the period of 1920 through 1950, the United States seized the opportunity and embarked on an imperialist mission into the Middle East" (Quinn, 2009, p. IV). It is not by accident that imperialism and scholarship dwell on together and traverse simultaneously. The spirit of this stage is asserted by the then President George W. Bush in 2000 saying "our nation is chosen by God and commissioned by history to be a model to the world of justice and inclusion and diversity without division. These are American convictions" (2000). This superiority of America served as both a foil by which America maintains a hegemonic position and as a confirmation of the inferiority of the Other:

Our opponents like to talk about American exceptionalism...forget that we're exceptional, not because we say we are, but because we do exceptional things. We break out of the Great Depression, win two World Wars, save lives fighting AIDS, pull people out of poverty, defend freedom, go to the moon and produce exceptional people who even give their lives for civil rights and human rights... an exceptional country does care about the rise of the oceans and the future of the planet...that is a responsibility from the Scriptures (Kerry, 2012).

\section{Creation of Israel and American Interests in Middle East}

Modern American Orientalism is shaped by the relentless political and military engagement in the Middle East. Two main important factors played the major role in shaping the second phase of American orientalism can be summarized here. Firstly, creation of Israel in May 1948 and the American entire support to Zionism frustrated the Orient physically and literally. American orientalism at this stage propagated modernizing Arab world as an essential need; at this particular stage Arabs were represented in American popular culture as aggressive and primitive nomads whose land is not utilized:

If the Arab occupies space enough for attention it is a negative value. He is seen as a disrupter of Israel's or the West's existence...Palestine was imagined as an empty desert waiting to burst into bloom, its inhabitants inconsequential nomads possessing no stable claim to the land and therefore no cultural permanence. Thus the Arab is conceived of now as a shadow that dogs the Jew (Said, 1977, p. 286).

Israeli wars with Arabs are vital aspects in evaluating the image of Arabs in American writings. Many American writers consider the credibility and reliability of political statements during the wars as a source of final assessment: "No preconceptions seem to have had a greater impact on analytical attitudes that those concerning relative Arab and Israeli military prowess" (Kam, 1988, p. 124). The Israeli victories were by no means perceived as a fulfillment of U.S. foreign policy assumptions on the superiority of Jews on Arabs. The wars of 1967 and 1973 grew in American writings to even give them a biblical color: "Opinion polls taken shortly after 
the shooting stopped showed that Americans sympathizing with Israel outnumbered those sympathizing with the Arabs by a whopping 19-to-1 ratio...[M] ost Americans seemed to regard Israel's smashing victory as the fulfillment of a biblical prophecy" (Little, 2002, p. 32). In 1971 a CIA report refers to the Arab soldier as a man who "lacks the necessary physical and cultural qualities for performing effective military services" (quoted. Cumming, 2013, p. 91). The implications of these wars were further spelled out by the American policy-makers in 1976 that "Arabs, as Arabs, simply weren't up to the demands of modern warfare and that they lacked under-standing, motivation, and probably in some cases courage as well" (Dowty, 1984, p. 204).

These perceptions prevailed in the 1960s and 1970s and completed the transformation of the Arabs from uncivilized and weak into fools who are devoted to defeat and deceit. This appraisal is summarized by Henry Kissinger in a reported conversation with Golda Meir, the then Israeli Prime Minister:

We and you were both convinced that the Arabs had no military option which required serious diplomatic action. Instead of doing something we joked about the shoes the Egyptians left behind in 1967. Do you remember when I reported to you on my meeting with Hafez Ismail in Washington? What did I do in those conversations? I talked with him about the weather and every subject in the world just so we wouldn't get to the subject the minister thought most important. I played with him. I toyed with him...I regarded it as empty talk, a boast empty of content. He invited me to come to Egypt...But I did not dream of a trip to Cairo. Who is Sadat? We all thought that he was a fool, a clown. A buffoon who goes on a stage every other day to declare war (1984, pp. 208-209).

Secondly, the expansion of American interests in the region led to assumptions that American imperialism is a challenge to the autonomy and supremacy of the newly independent countries and therefore, an enduring feature of American orientalism during this era resulted from the political relationship between Arabs and the US. One particular aspect of this orientalism is that it has captured the interest of writers to represent Arabs as wealthy Sheikhs of oil. This early modern American orientalism is always referred to with a special focus on the role of oil and the concurrent rise of American hegemony. American orientalism, during the discovery of huge oil fields in Arabia, produced a very different picture from dominant images in classic orientalisms and was discernible in themes and spirit of writers. This era in American orientalism was a time of fruition of a longer process of imitating the European orientalisms and marked by a real American challenge to supremacy of Britain in the region. This does not mean, however, that American orientalists change the subject matter. On the contrary, they enjoyed an interesting shift in themes and positioned American orientalism in a stronger place than ever.

American cultural interest in the orient was hard to extricate from its hegemonic and imperial interests. The two, however, are connected to each other. On his comment this kind of relationship, Michel Foucault states that "we should admit rather that power produces knowledge...power and knowledge directly imply one another...there is no power relation without the correlative constitution of a field of knowledge" (1977, p. 27). American orientalism associated with the American access to Arab oil produced enormous representations of Arabs and determined the future compelling characteristics of orientalism. For example in On the Brink (1977) and The Delta Force (1986), Arabs are associated with terror, aggression, backwardness; they are "crafty oil magnates who care nothing about the economic well-being of the world" (Terry, 1983, p. 26). Similarly, interest in oil resulted in American films on Arabs such as The Black Sunday (1977), The Three Kings (1999) and Ben Hur (1959). In these films, Arabs are introduced as "ragheads," "aliens" in "bedsheets," irrational religious fanatics who wave Kalashnikovs instead of swords and undertake suicide terrorist missions in place of cavalry charges, and wealthy "petroshiekhs" (Simon, 2010, p. 90). American orientalist academia stressed that Arabs are either terrorists who insist on destroying the West or as oil-wealthy Sheikhs who care about nothing but controlling the West economy.

\section{America and Islamic Groups}

An important factor has contributed to the unabashed stereotyping of the Middle East and its people in American writing. More than anything else, what accounts for modern American orientalism is the terrorist attacks against American interests and the American relentless political and military engagement in the Middle East. Since the 1980s, terrorist groups from Arab countries and the United States have been struggling against each other to find meanings in the random terrorist attacks and the American retaliation. These interactions between the United States and the terrorist groups motivated by politics rather than religious bigotry though the two opponents happen to represent holy warriors and holiness of their fight. Therefore, the last twenty years of the twentieth century provide a fertile ground for representing Arabs; and therefore, any discussion on modern American orientalism must refer to this military aspect as a basis for study. Writings on Arabs at this stage are divided into two categories. The first, comprising the major texts, is the fiction category consisting of crime fiction, 
detectives, thrillers and spy stories. The second category, containing less volume yet more important, comprises historical novels that investigate the emergence of Islam, Islamic culture and Prophet Mohammed. These novels, though modern, demonstrate long histories of political and cultural tensions shaping the image of the Arabs that served, for long, a variety of purposes "including religious authorities, political establishments, and corporate-media conglomerates, conceptualize for their consumers image of Muslims and/or Arab in sometimes amusing and other time cruel or tragic ways" (Progler, 2011, p. 233). This spirit continues to gain currency in today's fiction too and some of the themes continued and developed.

The most recent genre in American orientalism is the 9/11 fiction. With the start of the twentieth century, one begins to see the glimmerings of extremely negative representation of Arabs in American writings. For an Arab reader, the darkest and most chilling images to emerge from orientalist academia in general date from 11 September 2001 when almost every American watched the horror of 9/11 in Ground Zero. From that date America writing on the Middle East was preoccupied with fighting Islamic terrorism and introducing Islamic figures to the readers. This latest genre of American orientalist writing deals with three main themes: Islamic terrorism, Islamic fundamentalism and Islam as entity; the latter encompasses investigations of the Islamic beliefs, Prophet Muhammad and Khalifahs. American writing on these themes is not new but a continual literary tradition in which Arab Muslims are consistently vilified. Post 9/11 American writers were appalled by the horror of the 9/11 events and the awful news that followed and indeed, the themes, the imagery and the language assigned to describe the Arabs ushered in another phase of American orientalism.

In post 9/11 American orientalism, very few writers, if any, try to highlight the political trends that constitute Arab-American relationship and figure out relationship between terrorism and imperialism and set the religion apart from scene. And instead of focusing on the nature of the terrorism and how certain persons become terrorists, most of the writers focus on issues related to the religion, the Prophet Muhammad, details in Muhammad's personal life and historical Islamic figures who passed away thirteen century ago. This "megaperspective" technique aggravated the image of the Arab Muslim by judging Arabs on the basis of the moral and behavioral of a small radical and terrorist group who committed 9/11 terrorist acts. This sinister image becomes dominant in American orientalism today. Nevertheless, rare distinctions were made between characters representing "moderate Arabs" as good Arabs and "radicle Arabs" as bad Arabs; the distinction does not spare the former from fanaticism, bigotry and chauvinism. For example, in Tom Clancy's The Teeth of the Tiger (2003), Richard A. Clarke's The Scorpion's Gate (2005), John Updike's Terrorist (2006) all Arab characters, the good and the bad, are part of a totality called Islam which harbors terrorism, hatred and anti-West attitudes. This negative reaction is extended to include the first Islamic generation of the $7^{\text {th }}$ century in John Elray's Khalifah (2002), Sherry Jones' The Jewel of Medina (2008) and its sequel The Sword of Medina (2009). In these novels, male figures are aggressive, fanatics, sexual wantons and anti-woman and females are submissive, obedient and committed hedonists. Similarly, Islam is conflated with Middle Easterners, Arab Muslims and Arab Christians and gains a highly negative picture to the extent that all turbaned people like the Sikhs are harassed and abused. After 9/11, Islam gains a political meaning and is viewed in terms of defining a relationship between the Orient and the United States in which Islam represents menace, backwardness and irrationality.

\section{Conclusion}

Since the $18^{\text {th }}$ century, American orientalism promoted volumes of images on Arabia, which depicted Arab Muslims as backward and aggressive and Muslim women as submissive and weak entities. These volumes of representations have been inherited from different orientalisms and got modified in the light of actual encounters to suit time and convince the public. Therefore, these images were made sharp and abusive according to certain historical events that came across Arab-America political relationship. From the end of the eighteenth century onwards, American writers depicted Arabs as animal-like nomads, kidnappers, irrational, untrustworthy and anti-America. Few changes on these dominant images took place over time. For example, terms like nomads and kidnappers got replaced by other words like backward and terrorists. Arab women have increasingly been the subject matter of American stories from early history of American orientalism and their representations have been influenced by political relationships. In The Blithedale Romance (1852), Twice-told Tales (1837) and The House of the Seven Gables (1850), Arab women's main duty is to stay at the harem to satisfy male sexuality. Through various stages in American orientalism, Arab woman's freedom was completely thwarted by confinement to the harem, a discursive concept that forms the basic tenet of the cultural strength of the American discourse on Arab woman. Similarly, Islam is represented as a religion without humanness and compassion. It is an institution that is incapable of understanding human norms and peaceful co-existing. By focusing on the orient and comparing it with the West, American orientalism has been an important tool for defining and consolidating national identity. 


\section{Acknowledgment}

The author acknowledges the financial support of this study by the grant no. 7240-EAR-2017-1-8-F from the Deanship of Scientific Research at Northern Border University, Arar, KSA.

\section{References}

Amin, S. (2004). U.S. Imperialism, Europe, and the Middle East. Monthly Review, 56(2), 2-6. https://doi.org/10.14452/MR-056-06-2004-10_2

Baepler, P. M. (2004). The Barbary Captivity Narrative in American Culture. Early American Literature, 39(2), 217-246. https://doi.org/10.1353/eal.2004.0022

Bilgin, P. (2004). Is the 'Orientalist' past the future of Middle East studies? Third World Quarterly, 25(2), 423-433. https://doi.org/10.1080/0143659042000174897

Bishara, M. (2013). US Goals and Strategies toward the Arab World. Siyasat Arabia, 1, 45-57. Retrieved from https://www.jstor.org/stable/resrep12710

Bryan, T. (1994). Orientalism, Postmodernism and Globalism. London: Routledge.

Bush, G. W. (2000). Remarks at the Simon Wiesenthal Center in Los Angeles. American Presidency Project. Retrieved July 19, 2017, from http://www.presidency.ucsb.edu/ws/?pid=85242

Chomsky, N. (1991). After the Cold War: U. S. Foreign Policy in the Middle East. Cultural Critique, 19, 14-31. https://doi.org/10.2307/1354305

Cumming, R. (2013). The African American Challenge to Just War Theory: A Christian Approach. New York: Palgrave Macmilan. https://doi.org/10.1057/9781137350329

Derrida, J. (1992). The Other Heading: Reflections on Today's Europe. Bloomington: Indiana University Press.

Digital History. (2014). The United States Becomes a World Power. Retrieved July 12, 2017, from http://www.digitalhistory.uh.edu/disp_textbook.cfm?smtID $=2 \& p s i d=3158$

Dowty, A. (1984). Middle East Crisis: U.S. Decision-making in 1958, 1970 and 1973. California: University of California Press.

Emerson, R. W. (1981). The American Scholar in The Portable Emerson. New York: Penguin Books Ltd.

Foucault, M. (1977). Discipline and Punish. New York: Vintage Books.

Harvey, D. (2003). The New Imperialism. New York: Oxford University Press.

Hyde, C. (2013). Unlearning a Great Many Things: Mark Twain, Palestine, and American Perspectives on the Orient. Dublin: Trinity College.

Jefferson, T. (1795). Thomas Jefferson to Tench Coxe. Library of Congress. Retrieved June 3, 2018, from https://www.loc.gov/exhibits/jefferson/181.html

Jefferson, T. (1826). Letter from Thomas Jefferson to Roger C. Weightman. Library of Congress. Retrieved June 11, 2018, from https://www.loc.gov/exhibits/declara/rcwltr.html

Kam, E. (1988). Surprise Attack: THe Victim's Perspective. Massachusetts: Harvard University Press. https://doi.org/10.4159/harvard.9780674493957

Kennedy, J. F. (1961). Inaugural Address. The American Presidency Project. Retrieved March 5, 2018, from (January 20, 1961). http://www.presidency.ucsb.edu/ws/?pid=8032

Kerry, J. (2012). Address to the Democratic National Convention. Charlotte, Retrieved June 9, 2018, from https://www.washingtonpost.com/politics/ -2012-kerrys-speech-to-the-democratic-convention.html

Lambert, F. (2007). The Barbary Wars: American Independence in the Atlantic World. New York: Hill and Wang.

Lemon, J. T. (1987). Colonial America in the Eighteenth Century in North America: The Historical Geography of a Changing Continent. Ed. Robert D. Mitchell and Paul A. Groves: 121-146. Totowa, New Jersey: Rowman and Littlefield.

Little, D. (2002). American Orientalism: The United States and the Middle East Since 1945. The University of North Carolina Press.

Louis, D., \& Cottineau K. (1806). Geographic Compilation for the Use of Schools: Being an Accurate Description of all the Empires, Kingdoms, Republics, and States in the Known World. Baltimore: Compiler. 
Moneim, A., \& Edward, S. W. (2004). An Arab-American Relationship for the 21st Century. Washington, D.C: Middle East Institute.

Progler, J. A. (2011). The Utility of Islamic Imagery in the West. al-Tawhid Islamic Journal, 14(4), $233-246$.

Quinn, J. W. (2009). American Imperialism in the Middle East: 1920-1950. Unpub. Thesis. North Carolina: Wake Forest University.

Said, E. (1997). Orientalism. London: Penguin.

Simon, R. S. (2010). Spies and Holy Wars: The Middle East in 20th-Century Crime Fiction. Austin: University of Texas Press.

Terry, J. J. (1983). Arab Stereotypes in Popular Fiction. Indiana Social Studies Quarterly, 36, $24-27$.

Walton, G. M., \& Hugh, R. (2010). History of the American Economy (11th ed.). Mason, OH: South-Western, Cengage Learning.

Young, R. (2004). White Mythologies: Writing History and the West. London: Routledge. https://doi.org/10.4324/9780203461815

\section{Copyrights}

Copyright for this article is retained by the author, with first publication rights granted to the journal.

This is an open-access article distributed under the terms and conditions of the Creative Commons Attribution license (http://creativecommons.org/licenses/by/4.0/). 